ROCZNIKI TEOLOGICZNE

Tom LXVIII, zeszyt $10-2021$

DOI: https://doi.org/10.18290/rt.216810.11

BOGDAN KULIK MSF

\title{
APOSTOLSTWO DOBREJ ŚMIERCI - DUSZPASTERSTWO, FORMACJA, DZIAŁALNOŚĆ WYDAWNICZA I NAUKOWA
}

\author{
APOSTOLATE OF GOOD DEATH \\ - PASTORAL MINISTRY, FORMATION, PUBLISHING AND SCIENTIFIC RESEARCH
}

A b s t r a c t. The article is a detailed analysis of activity of the Apostolate of Good Death, written to show specific ways of proclamation of Christian hope for eternal life. That issue has been raised on the grounds of COVID-19 pandemic, which showed the need of constant reminding of human's eternal life dimension. The study of the Apostolate's activity focuces on its main forms and shows a major role of the Apostolate in popularizing estachological mentality, during and after the pandemic.

Key words: good death; apostolate; pastoral work; formation.

Benedykt XVI jeszcze podczas swojego pontyfikatu przypominał: „Biorąc pod uwagę wrodzony lęk przed końcem, a bardziej jeszcze kulturę, która na różne sposoby stara się nie dopuszczać do głosu rzeczywistości i ludzkiego doświadczenia śmierci, liturgia wielkopostna z jednej strony przypomina nam o umieraniu, ukazując potrzebę realizmu i mądrości, a z drugiej zachęca, byśmy przede wszystkim dostrzegli nieoczekiwaną nowość, jaką wiara chrześcijańska wnosi w rzeczywistość śmierci, i byśmy nią żyli"1.

Ks. dr Bogdan KuliK MSF - Wydział Teologiczny, Uniwersytet im. Adama Mickiewicza w Poznaniu; ul. Wieżowa 2/4, 61-111 Poznań; adres do korespondencji: Górka Klasztorna, Rataje 48, 89-310 Łobżenica; e-mail: kulikbogdan@op.pl; ORCID: https://orcid.org/0000-0002-8627-3821.

${ }^{1}$ Benedykt XVI, „Nawrócenie oznacza dążenie do wysokiej miary życia chrześcijańskiego, Rzym 17.02.2010”, Opoka; dostęp: 07.04.2021, http://www.opoka.org.pl/biblioteka/W/WP/bened ykt_xvi/audiencje/ag_17022010.html. 
Pojawienie się uciążliwej dla ludzi na całym świecie pandemii spowodowanej wirusem wywołującym COVID-19 potwierdziło słowa papieża Benedykta XVI na temat stosunku człowieka do śmierci, a także konieczność nieustannego podejmowania na nowo tematu życia i umierania $\mathrm{w}$ świetle Ewangelii. Rodzi się zatem pytanie aktualne w każdym czasie, a w czasie pandemii nabierające szczególnego znaczenia: w jaki sposób głosić wspomnianą przez papieża Benedykta nowość wnoszoną przez wiarę w Chrystusa w nasze myślenie o śmierci?

Zadaniem tym zajmuje się od dawna Apostolstwo Dobrej Śmierci (ADS lub ADŚ), znane także jako Stowarzyszenie Matki Bożej Patronki Dobrej Śmierci². Dzieło to zostało oficjalnie ustanowione w 1908 roku przez Piusa X i obecnie znajduje się pod duszpasterską opieką Misjonarzy Świętej Rodziny, którzy w 2021 roku obchodza jubileusz 100-lecia posługi w Polsce ${ }^{3}$.

Biorąc po uwagę główne formy działalności Apostolstwa dzisiaj, którymi są: duszpasterstwo, formacja oraz aktywność wydawnicza i naukowa, w niniejszym artykule zostanie podjęta próba odpowiedzi na dwa pytania: w jaki sposób Stowarzyszenie obecnie głosi nadzieję chrześcijańską uzdalniającą do postrzegania i przeżywania śmierci człowieka w nowy, czyli zgodny z Ewangelią, sposób? Czy podejmowane działania są wystarczające?

\section{DUSZPASTERSTWO}

W ciągu ponadtrzydziestoletniej historii polskiej filii $\mathrm{ADS}^{4}$ zostały wypracowane następujące formy duszpasterstwa: rekolekcje parafialne, kazania okolicznościowe (np. z okazji założenia w parafii nowej wspólnoty ADS lub jubileuszu wspólnoty już istniejącej), spotkania opłatkowe.

Duszpasterze ADS, na zaproszenie księży proboszczów, głoszą rekolekcje wielkopostne, adwentowe lub inne (np. przygotowujące do odpustów parafialnych) uwzględniając przede wszystkim zagadnienia związane z chrześcijańską ars moriendi i katolicką eschatologią. Rekolekcje zwieńczone są prezentacją

\footnotetext{
${ }^{2} \mathrm{~W}$ statucie francuskim czytamy: L'Association de Notre-Dame de la Bonne Mort, appelée aussi par les Souverains Pontifes „Apostolat de la Bonne Mort” (bp Jean-Claude Boulanger, List do ks. Prowincjata Polskiej Prowincji Misjonarzy Świętej Rodziny W. Burzawy MSF [Sées 24.11.2004]). W artykule obydwie nazwy będą używane zamiennie.

${ }^{3}$ Odnośnie do historii powstania i celów szczegółowych Apostolstwa zob.: Bogdan Kulik, „Apostolstwo Dobrej Śmierci - historia i misja”, Roczniki Teologiczne 67(2020), 10: 81-92.

${ }^{4}$ Skrót oznacza: „Apostolstwo Dobrej Śmierci”.
} 
Stowarzyszenia i - jeśli odpowiada to wizji duszpasterskiej miejscowych pasterzy - propozycją utworzenia wspólnoty ADS w danej parafii. Powstanie wspólnoty wiąże się z ustanowieniem przez księdza proboszcza: odpowiedzialnego za nią kapłana oraz świeckiego zelatora. W wielu parafiach wspólnoty Apostolstwa mają swój sztandar, który jest nieobowiązkowym znakiem rozpoznawczym wspólnot ADS na tle innych grup. Utworzenie nowej wspólnoty możliwe jest także przy okazji głoszenia okolicznościowych kazań (najczęściej niedzielnych), w których porusza się tematy związane z misją Stowarzyszenia.

W celu propagowania Stowarzyszenia duszpasterze ADS głoszą także konferencje informacyjno-formacyjne na zaproszenie różnych grup i wspólnot (np. duszpasterstwa akademickiego, duszpasterstwa służby zdrowia, dla pracowników hospicjów) 5 .

Inną formą duszpasterstwa jest utrzymywanie regularnego kontaktu z istniejącymi wspólnotami ADS w Polsce i za granicą na corocznych spotkaniach opłatkowych. Służą one nie tylko do umocnienia więzi pomiędzy członkami Stowarzyszenia i ich duszpasterzami, ale są także okazją do bezpośredniego przekazania informacji z centrali ADS, omówienia bieżących problemów we wspólnotach oraz dystrybucji nowych materiałów formacyjnych.

Mimo że statuty Stowarzyszenia nie zobowiązują jego duszpasterzy i członków do podejmowania specjalistycznej posługi wobec chorych i umierających (np. w szpitalach, domach pomocy czy hospicjach), jednak wiele osób, przynależących do Apostolstwa w swoich parafiach, spieszy w roli wolontariuszy z posługą chorym w domach i placówkach opiekuńczych.

$\mathrm{Z}$ najnowszych inicjatyw duszpasterskich Stowarzyszenia warto wspomnieć: założenie nowej wspólnoty w Tanzanii ${ }^{6}$; odwiedzenie istniejących i założenie nowych wspólnot ADS w Stanach Zjednoczonych Ameryki ${ }^{7}$; uzyskanie pozwolenia kurii biskupiej na działalność w diecezji Freiburg w Niemczech oraz starania o to w diecezji wiedeńskiej. Poza tym od roku 2018 na

\footnotetext{
${ }^{5}$ Np. 30 października 2018 roku w Łodzi, w siedzibie Duszpasterstwa Akademickiego „Kamienica”, duszpasterze ADS zaprezentowali charyzmat Stowarzyszenia i podstawy eschatologii katolickiej studentom łódzkich uczelni; w dniach 6-8 kwietnia 2018 roku w Kluczborku odbyły się rekolekcje dla pracowników hospicjów diecezji opolskiej, a 15 listopada 2018 roku w Bielsku-Białej spotkanie modlitewno-formacyjne dla członków Duszpasterstwa Służby Zdrowia Diecezji Bielsko-Żywieckiej.

${ }^{6}$ Zob. Lidia Wajdzik, „Apostolstwo na Czarnym Lądzie”, Nadzieja i Życie 1(2019): 11-15.

${ }^{7}$ Zob. Bogdan Kulik, „ADS z Manhattanem w tle”, Nadzieja i Życie 2(2020): 15-20.
} 
prośbę Wspólnoty Rodziców po Stracie Dziecka, duszpasterze Apostolstwa włączają się w prowadzenie rekolekcji dla jej członków ${ }^{8}$.

Duszpasterze wraz z zelatorami i członkami Apostolstwa starają się także o propagowanie misji Stowarzyszenia poprzez obecność medialną, która jest swoista formą duszpasterstwa. Warto zatem wspomnieć: audycje radiowe (,Radio Maryja”, rzeszowskie „Radio Via”, „Radio Kraków”) i transmisje spotkań ADS (Radio „Anioł Beskidów”) ${ }^{9}$; seria programów pt. „Pogadajmy bez ogródek" w TVP Bydgoszcz ${ }^{10}$; wywiady w prasie katolickiej ${ }^{11}$ i w Internecie ${ }^{12}$.

Szczególną pomocą w działalności duszpasterskiej Apostolstwa Dobrej Śmierci jest strona internetowa: apostolstwo.pl, na której można znaleźć wszystkie podstawowe wiadomości w kilku językach, oraz bieżące informacje o ADS. Poprzez tę stronę można także dokonać elektronicznego zgłoszenia członkostwa w Stowarzyszeniu oraz zamówić prenumeratę biuletynu Nadzieja $i$ Życie.

Mimo utrudnień wynikających z pandemii Apostolstwo nie zaprzestało swojej aktywności duszpasterskiej, która owocuje rozwojem wspólnoty. Według ostatnich danych ${ }^{13}$ w roku 2020 wpisały się do Stowarzyszenia 1134 osoby, przybyło 13 nowych zelatorów, a kazania na temat Apostolstwa wygłoszono w 16 parafiach. Rekolekcje z uwzględnieniem tematyki Apostolstwa przeprowadzono w 10 parafiach, a w ośrodkach rekolekcyjnych w kraju odby-

\footnotetext{
${ }^{8}$ Zob. „Rekolekcje: Co chcesz abym ci uczynił? Gdynia 16-18.03.2018”, Wspólnota Rodziców Po Stracie Dziecka; dostęp: 08.04.2021, http://www.stratadziecka.pl/aktualnosci/wydar zenia/35896/rekolekcje-co-chcesz-aby-ci-uczynil; „,Rekolekcje: Nadzieja zawieść nie może. Gdynia 22-24.03.2019”, Wspólnota Rodziców Po Stracie Dziecka; dostęp: 08.04.2021, http://www.s tratadziecka.pl/aktualnosci/wydarzenia/45869/rekolekcje-nadzieja-zawiesc-nie-moze;,,Rekolekcje: W Twoich ranach jest nasze zdrowie. Straszyn 6-8.03.2020”, Wspólnota Rodziców Po Stracie Dziecka; dostęp: 06.04.2021, http://www.stratadziecka.pl/aktualnosci/wy darzenia/59193 /rekolekcje-06-08-03-2020-straszyn.

9 Audycje i transmisje są dostępne na stronie internetowej, zob. „Rozmowy o życiu, śmierci i wieczności”, Apostolstwo Dobrej Śmierci; dostęp: 06.04.2021, https://apostol stwo.pl /multimedia/posluchaj-nas.

${ }^{10}$ Filmy dostępne także jako: „Pogadajmy bez ogródek”, Apostolstwo Dobrej Śmierci, dostęp: 12.04.2021, https://apostolstwo.pl/multimedia/pogadajmy-bez-ogrodek.

${ }^{11}$ Zob. „Wywiady o tematyce ADS”, Apostolstwo Dobrej Śmierci, dostęp: 06.04.2021, https://apostolstwo.pl/o-ads/charyzmat-ads/wywiady.

12 „Memento mori - spotkanie online”, YouTube: Wydawnictwo W drodze; dostęp: 12.04. 2021, https://www.youtube.com/watch?v=rjHfxQgTh-M.

${ }^{13}$ Grzegorz Górnik, Sprawozdanie z działalności Filii Stowarzyszenia Matki Bożej Patronki Dobrej Śmierci w Polsce z siedziba w Sanktuarium Maryjnym w Górce Klasztornej za rok 2020 (Górka Klasztorna, 2021).
} 
ły się 2 serie rekolekcji Apostolstwa, w których uczestniczyło ok. 100 osób. Regionalne spotkania opłatkowe z udziałem duszpasterzy Apostolstwa odbyły się w 24 miejscowościach, a w 5 przeprowadzono regionalne dni skupienia ADS. W Księdze Stowarzyszenia w Górce Klasztornej zostało więc zapisanych od powstania polskiej filii w 1987 roku do chwili obecnej ok. 581000 osób, natomiast do Księgi Zmarłych 1784 osoby. Liczba zelatorów, łącznie $\mathrm{z}$ ich zastępcami oraz z tzw. zelatorami honorowymi ${ }^{14}$, wynosi ok. 1100.

\section{FORMACJA CZŁONKÓW}

Duszpasterze Apostolstwa starają się zapewnić możliwość formacji ciaggłej członkom Stowarzyszenia. $\mathrm{Z}$ tego względu co roku prowadzą dla nich ok. 7 serii rekolekcji w ośrodkach na terenie całego kraju (np.: Górka Klasztorna k. Piły, Białystok, Gietrzwałd, Radomyśl k. Sandomierza, Niechobrz k. Rzeszowa, Kluczbork, Katowice, Brenna k. Skoczowa).

Regularnie organizowane są także doroczne, regionalne dni skupienia. W ich programie obok czasu na wspólną modlitwę przeznaczono także miejsce na konferencje formacyjne. Dni skupienia odbywają się zwykle w: Górce Klasztornej, Wilnie, Turzy Śląskiej (diecezja katowicka), Szwedzkiej Górce (diecezja opolska), Katowicach, Pierśccu (diecezja bielsko-żywiecka), BielskuBiałej Hałcnowie. Oprócz tego dni skupienia są organizowane w parafiach, przy okazji uroczystości jubileuszowych z okazji rocznic powstania wspólnot ADS. W ramach formacji zelatorów Apostolstwa odbywają się co roku w Katowicach przeznaczone dla nich spotkania formacyjne przygotowane i prowadzone przez ks. dyrektora Apostolstwa Dobrej Śmierci, którym obecnie jest ks. Grzegorz Górnik MSF ${ }^{15}$.

Najbardziej podstawową i powszechną formą pogłębiania duchowości i wiedzy członków Apostolstwa są comiesięczne spotkania modlitewno-formacyjne w parafiach, w których istnieja wspólnoty ADS. W większości z nich sprawowana jest comiesięczna Eucharystia w intencji żywych i zmarłych członków Apostolstwa, odbywa się adoracja Najświętszego Sakramentu, odmawiany jest Różaniec

\footnotetext{
14 Tytuł ten przyznawany jest zelatorowi w chwili, gdy z powodu wieku lub stanu zdrowia nie może pełnić już czynnej posługi odpowiedzialnego za wspólnotę ADS.

${ }^{15}$ Aktualny „Terminarz” wszystkich rekolekcji i spotkań ADS publikowany jest w biuletynie Nadzieja i Życie oraz na stronie: apostolstwo.pl, zakładka „Aktualności”.
} 
do Siedmiu Boleści Matki Bożej ${ }^{16}$. Dodatkowo, w wielu z nich, kapłani odpowiedzialni za wspólnotę głoszą konferencje formacyjne.

W ramach Apostolstwa propagowana jest Nieustanna Modlitwa Wstawiennicza, która skupia już blisko 2000 osób. Każdego dnia, o stałej porze, osoby chętne modlą się: za konających, terminalnie i nieuleczalnie chorych; za rodziny osierocone po śmierci najbliższych; o nowe, liczne i święte powołania kapłańskie, zakonne, misyjne i hospicyjne; o łaskę wiary i nawrócenia dla obojętnych religijnie i grzeszników oraz w intencjach Apostolstwa. Ta forma modlitwy jest przygotowaniem do godnego i chrześcijańskiego przeżywania śmierci ${ }^{17}$.

Ponieważ pandemia spowodowała utrudnienia w prowadzeniu regularnych spotkań z członkami Stowarzyszenia, dlatego by nie zaniedbać działalności formacyjnej i ewangelizacyjnej powstały dwa cykle filmików publikowanych regularnie w Internecie: „Stąpając twardo po ziemi”"18 oraz „60 sekund o wieczności"19. Ich celem jest przypominanie misji Apostolstwa oraz zapoznawanie widzów z kolejnymi zagadnieniami chrześcijańskiej eschatologii i duchowości ars moriendi.

\section{DZIAŁALNOŚĆ WYDAWNICZA I NAUKOWA}

W celu propagowania Apostolstwa i chrześcijańskiej wizji życia i śmierci prowadzona jest działalność wydawnicza i informacyjna ${ }^{20}$, w ramach której

\footnotetext{
${ }^{16}$ Modlitwa ta stała się tradycyjną modlitwą ADS. Na temat Różańca do Siedmiu Boleści zob.: Curia Generalis OSM, Corona dell'Addolorata. Celebrazione della Compassio Virginis (Roma, 1986), Józef Kopeć, „Koronka”, w Encyklopedia Katolicka, t. 9, red. Andrzej Szostek, Bogusław Migut (Lublin: Towarzystwo Naukowe KUL, 2002), 888-890; także: Maria M. Muraro, Maria M. Pedico, „Addolorata”, w Mariologia, red. Stefano De Fiores, Valeria Ferrari Schiefer, Salvatore M. Perrella (Cinisello Balsamo, Milano: San Paolo, 2009), 14; Maria M. Pedico, El culto de la Virgen de los Dolores desde 1848 a 1950 en la Orden de los Siervos de Maria, 9-11; dostęp: 06.04.2021, http://servidimaria.net/sitoosm/es/historia/congu no/11.pdf. Na temat polecenia przez Maryję tej modlitwy podczas objawień w Kibeho zob.: Edouard Sinayobye, Jestem Matka Stowa. Nasza Pani z Kibeho. Przebudzenie na nasze czasy (Ząbki: Apostolicum, 2016), 107-109.

${ }^{17}$ Do Nieustannej Modlitwy Wstawienniczej można dołączyć poprzez dobrowolny wpis także drogą internetową na stronie: apostolstwo.pl, zakładka „O ADS/Nieustanna Modlitwa”.

18 „Stąpając Twardo Po Ziemi”, Apostolstwo Dobrej Śmierci; dostęp: 06.04.2021, https://a postol stwo.pl/multimedia/stapajac-twardo-po-ziemi.

19 „60 sekund o wieczności”, Apostolstwo Dobrej Śmierci; dostęp: 06.04.2021, https://a postolstwo.pl/multimedia/60-sekund-o-wiecznosci.

${ }^{20}$ Już we wczesnych latach swego istnienia we Francji Apostolstwo zajmowało się wyda-
} 
wydawane są książki ${ }^{21}$, broszury informacyjne ${ }^{22}$, kalendarze, ulotki, karnety modlitewne i inne materiały ${ }^{23}$. Niektóre $\mathrm{z}$ inicjatyw zasługuja na szczególną uwagę.

Stowarzyszenie posiada swój kwartalnik, biuletyn formacyjno-informacyjny pt. Nadzieja $i \dot{Z} y c i e^{24}$. Wśród publikowanych w nim tekstów znajdują się przede wszystkim: artkuły popularnonaukowe o tematyce ars moriendi, eschatologicznej i mariologicznej; świadectwa i refleksje; sprawozdania z działalności wspólnot ADS i inne. W każdym numerze umieszczana jest „Kronika Apostolstwa”, czyli wykaz inicjatyw Stowarzyszenia w minionym kwartale oraz „Terminarz spotkań” informujący o najbliższych wydarzeniach ${ }^{25}$. Biuletyn jest redagowany przez duszpasterzy, zelatorów, członków i sympatyków Apostolstwa.

Kolejną, cyklicznie ukazującą się od 2016 roku, pozycją wydawniczą są Materiały formacyjne wydawane co roku do użytku wewnętrznego Stowarzyszenia. Posiadają formę 12 konspektów dotyczących tematyki związanej z misją Apostolstwa. Każdy konspekt zawiera: pytania do osobistej refleksji; nauczanie Pisma Świętego i Katechizmu Kościoła Katolickiego ${ }^{26}$; krótki

waniem książek i materiałów mających na celu propagowanie swojej misji i formację jego członków. Warto wspomnieć chociażby Rękopis z czyśćca. Jego francuski oryginał został powierzony Apostolstwu Dobrej Śmierci z Tinchebray i został wydany dzięki staraniom jego władz; zob. Anne-Guillaume Vernaeckt, „Préface”, w Sanctuaire de Montligeon. Le Manuscrit du Purgatoir (Paris: Pierre Téqui, 2013), 5. Tekst ukazał się także w j. polskim: Adam Skwarczyński, red., Rękopis z czyśćca (Marki: Michalineum, 2008).

${ }^{21} \mathrm{~Np}$. Aleksandra Zapotoczny, Wszystko postawiliśmy na Maryje (Pelplin: Bernardinum, 2015).

${ }^{22}$ Np. Stanisław Kania, red., Apostolstwo Matki Boskiej Patronki Dobrej Śmierci (Kraków: Wydawnictwo Zakonu Pijarów, 1992); Stowarzyszenie Matki Boskiej Patronki Dobrej Śmierci (Pelplin: Bernardinum, 1996); Roman Siatka, red., Historia Stowarzyszenia Matki Bożej Patronki Dobrej Śmierci (Pelplin: Bernardinum, 2008).

${ }^{23}$ Niektóre z nich można zobaczyć i zamówić na stronie internetowej: apostolstwo.pl w zakładce „Materiały”.

${ }^{24}$ Biuletyn Polskiej Filii ukazuje się regularnie od 1996 roku i jest kontynuacją wydawanego we Francji biuletynu L'espoir e vie, którego pierwszy numer opublikowano w Rzymie, w lipcu 1908, czyli jeszcze w tym samym miesiącu, w którym Pius X ogłosił Stowarzyszenie uniwersalnym. Wcześniej, w Tinchebray, ukazywał się okólnik, który był wydawany, gdy Stowarzyszenie miało jeszcze charakter dzieła regionalnego, zob. Association de Notre-Dame de la Bonne-Mort. Notice Historique (Tinchebray: Lorfeuvre, 1963), 11-12,26,28; Stowarzyszenie Matki Boskiej, 30,34.

${ }^{25}$ Spis treści każdego numeru oraz „Terminarz” dostępne są także na stronie internetowej: apostolstwo.pl w zakładkach: „Materiały/biuletyn” i „Aktualności”.

${ }^{26}$ Katechizm Kościoła Katolickiego (Poznań: Pallottinum, 1994). 
tekst do przemyślenia zaczerpnięty z dokumentów Kościoła lub dzieł teologów katolickich. Taka struktura Materiatów pozwala na użycie ich przez duszpasterzy i zelatorów podczas spotkań formacyjnych, ale także nadaje się do osobistej lektury osób zainteresowanych tematem życia, śmierci i wieczności ${ }^{27}$. Na rok 2021 został przygotowany zeszyt zatytułowany Wieczność ze św. Janem Pawtem II, który może stanowić pewne kompendium eschatologii polskiego papieża zawartej w Jego katechezach wygłaszanych podczas środowych audiencji generalnych w Watykanie ${ }^{28}$.

Za bardzo cenną pomoc duszpasterską i formacyjną należy uznać broszurę pt. Metoda asystowania umierajacym ${ }^{29}$. Jej autorem jest ks. Jan Berthier MS, założyciel Zgromadzenia Misjonarzy Świętej Rodziny. Metoda to tekst wpisujący się w tradycję gatunku ars bene moriendi, czyli dzieł powstających szczególnie, ale nie tylko w okresie późnego średniowiecza, jako praktyczne poradniki przygotowywania siebie i innych do dobrej, chrześcijańskiej śmierci ${ }^{30}$. Mimo że oryginał francuski pt. Méthode pour assister les mourants został wydany w 1898 roku ${ }^{31}$, treść Metody nie straciła nic ze swej aktualności.

Na uwagę zasługuje także przygotowany przez Misjonarzy Świętej Rodziny Modlitewnik Apostolstwa Dobrej Śmierci ${ }^{32}$. Ta zawierająca ponad 700 stron

\footnotetext{
${ }^{27}$ Materiaty formacyjne są udostępniane w wersji elektronicznej na stronie internetowej: apostolstwo.pl.

${ }^{28}$ Bogdan Kulik, red., Materiały formacyjne. Wieczność ze św. Janem Pawtem II (Pelplin: Bernardinum, 2020).

29 Jan Berthier, Metoda asystowania umierającym (Górka Klasztorna, 2015). Na temat historii, struktury i teologii tego dzieła zob.: Adam Bajorski, „Metoda asystowania umierajacym Księdza Jana Berthier jako model metody ogłaszania Królestwa Bożego”, w Cor unum et anima una. Księga Jubileuszowa ku czci księdza Jana Berthier Założyciela Zgromadzenia Misjonarzy Świętej Rodziny z okazji 100-lecia jego śmierci, red. Adam J. Sobczyk (Pelplin: Bernardinum, 2009), 95-101; Władysław Biedrzycki, „Przy łożu śmierci. Metoda towarzyszenia umierajacym ks. Jana Berthiera”, w Śmierć i wiara w życie pośmiertne w świetle nauk przyrodniczych i humanistycznych, red. Marian Machinek (Olsztyn: Hosianum, 2003), 257-267; Marian Machinek, „Towarzyszyć w ostatniej drodze. Metoda asystowania umierajacym ks. Jana Berthier a współczesna troska o umierających", w Cor unum et anima una, 79-94; Egon Färber, „Towarzyszyć umierającym. Pastoralne wskazówki duszpasterza Jana Berthiera MSF (18401908)" oraz ich dalszy rozwój w regułach zakonnych Misjonarzy Świętej Rodziny, cz. 1", Nadzieja i Życie 1(2017): 14-17; Egon Färber, „Towarzyszyć umierającym. Pastoralne wskazówki duszpasterza Jana Berthiera MSF (1840-1908) oraz ich dalszy rozwój w regułach zakonnych Misjonarzy Świętej Rodziny, cz. 2”, Nadzieja i Życie 3(2017): 4-7.

${ }^{30}$ Machinek, „Towarzyszyć w ostatniej drodze”, 85.

${ }^{31}$ Zob. Biedrzycki, „Przy łożu śmierci”, 260.

${ }^{32}$ Zob. Modlitewnik Apostolstwa Dobrej Śmierci (Pelplin: Bernardinum, 1999). Spis treści zob. apostolstwo.pl, zakładka: „Materiały/Książki ADS”.
} 
pozycja jest podstawowym modlitewnikiem członków Apostolstwa. Bogactwo zebranych modlitw na różne okazje, a także katechetyczne wprowadzenia, m.in. do celebracji sakramentów, czynią z Modlitewnika praktyczną pomoc duszpastersko-formacyjną.

W formacji duszpasterzy, zelatorów i członków ADS bardzo pomocną okazuje się działalność naukowa. Polega ona na podejmowaniu przez duszpasterzy Stowarzyszenia następujących inicjatyw: prowadzenia wykładów na uczelniach wyższych $^{33}$; studium zagadnień eschatologii katolickiej i związane z tym publikowanie artykułów w czasopismach naukowych ${ }^{34}$ oraz pozycji książkowych ${ }^{35}$; uczestnictwo w sympozjach i konferencjach naukowych ${ }^{36}$, a także ich współorganizacja. Na szczególną uwagę zasługuje zorganizowana wspólnie z Instytutem Liturgiki i Homiletyki Katolickiego Uniwersytetu Lubelskiego Jana Pawła II 18 listopada 2017 roku w Górce Klasztornej z okazji 30-lecia istnienia polskiej filii ADS konferencja naukowa pod hasłem: „Jest nadzieja, bo jest życie wiecz-

${ }^{33}$ Np. w semestrze zimowym 2017/2018 ks. Bogdan Kulik MSF prowadził na Wydziale Teologicznym Uniwersytetu im. Adama Mickiewicza w Poznaniu konwersatorium pt. Życie wieczne: strata, zysk czy ktamstwo. Zarys eschatologii pastoralnej.

${ }^{34}$ Np. Bogdan Kulik, „Od paruzji do «paruzjologii», czyli eschatologia w ujęciu Antoniego Nitroli”, Poznańskie Studia Teologiczne 28(2014): 195-211; tenże, „Dobra śmierć - czyli jaka? Próba odpowiedzi na pytanie na podstawie nauczania K. Rahnera, H.U. von Balthasara i J. Ratzingera (Benedykta XVI)”, Poznańskie Studia Teologiczne 31(2017): 85-115; tenże, „De arte moriendi Jana Gersona - średniowieczny przeżytek czy dar dla współczesnych? Próba analizy w świetle dokumentu Aktualne problemy eschatologii Międzynarodowej Komisji Teologicznej (1992)”, Teologia i Moralność 12(2017) 1/21: 185-203; tenże, „Jak mówić dziś w Kościele o śmierci? Śmierć w kontekście pastoralnym w świetle De mortalitate św. Cypriana z Kartaginy”, Teologia Praktyczna 19(2018): 155-172; tenże, „Czy możliwym jest, aby o umieraniu i wieczności pisać profesjonalnie, a zarazem interesująco? Uwagi na temat języka współczesnej eschatologii i dzieł ars moriendi”, Teologia i Moralność 14(2019), 1/25: 287-306. Kolejne artykuły są w trakcie publikacji.

35 Ireneusz Werbiński, Bogdan Kulik i Adam Sobczyk, Jak się nie zagubić w czasie $i$ w wieczności? Spotkanie z Chrystusem jako istota duchowości chrześcijańskiej i rzeczy ostatecznych człowieka (Włocławek: Włocławskie Wydawnictwo Diecezjalne, 2017), Spis treści zob. apostolstwo.pl, zakładka: „Materiały/Książki ADS”; Bogdan Kulik, Głosić rodzinie Ewangelię o życiu wiecznym (Pelplin: Bernardinum, 2021), Wstęp i Spis treści zob. apostolstwo.pl, zakładka: „Materiały/Książki ADS. W ostatniej z wymienionych publikacji poruszono m.in. następujące zagadnienia: związek sakramentu chrztu św. i sakramentu małżeństwa z życiem wiecznym; rola seksualności w perspektywie wieczności; kwestia duszpasterskiego towarzyszenia rodzicom zmarłych dzieci.

${ }^{36}$ Np. w Międzynarodowej Konferencji Naukowej z okazji 30-lecia Lubelskiego Towarzystwa Przyjaciół Chorych Hospicjum Dobrego Samarytanina „Przystanąć - Towarzyszyć - Wesprzeć”, która odbyła się 17.10.2019 r. w Katolickim Uniwersytecie Lubelskim Jana Pawła II. 
ne”. Stała się ona inspiracją do wydania pracy zbiorowej pod tymże tytułem ${ }^{37}$. Na rok 2022 planowana jest kolejna konferencja tym razem łącząca zagadnienia eschatologiczne i mariologiczne.

\section{ZAKOŃCZENIE}

Szczegółowa analiza działalności Apostolstwa pozwala na udzielenie odpowiedzi na, postawione we Wstępie artykułu, pytania: w jaki sposób Stowarzyszenie obecnie głosi nadzieję chrześcijańską? Czy podejmowane działania są wystarczające?

Należy przede wszystkim stwierdzić, że wskazane sposoby działalności Stowarzyszenia, a mianowicie: duszpasterstwo, formacja członków oraz aktywność wydawnicza i naukowa, mają na celu formowanie mentalności eschatologicznej, czyli myślenia o życiu i umieraniu w perspektywie nadziei zmartwychwstania i życia wiecznego. Głoszenie kazań, konferencji i rekolekcji, organizacja spotkań formacyjnych i sympozjów, aktywność w mediach, publikacja materiałów formacyjnych, artykułów naukowych i modlitewników, propozycje wspólnotowej i indywidualnej modlitwy w intencji dobrego przeżywania życia i przygotowania się do śmierci - wszystko to jest próbą odpowiadania z realizmem i mądrością na wrodzony lęk człowieka przed śmiercią, o którym mówił cytowany we Wstępie papież Benedykt XVI. Innymi słowy, Apostolstwu Dobrej Śmierci zależy na realizowaniu postulatu, jaki zawiera Nowa Karta Pracowników Stużby Zdrowia z 2016 r.: „Należy zatem nadać śmierci sens ewangeliczny" 38 . Każdy inny sposób patrzenia na ludzkie życie naznaczone śmiercią i umieraniem, jest niewystraczający, by nadać mu sens mimo wdzierającego się w serca i umysły poczucia bezsensu.

Czy podejmowane działania są wystarczające? Oczywistym jest, że obowiązek uświadamiania ludziom wiecznego charakteru ich życia i wypływającej z niego odpowiedzialności przekracza możliwości jednej tylko wspólnoty i jest zadaniem całego Kościoła. Jednak biorąc po uwagę przeanalizowana aktywność Apostolstwa Dobrej Śmierci wydaje się, że można uznać jego działania za satysfakcjonujące. W najbliższym czasie Stowarzyszenie powinno

\footnotetext{
${ }^{37}$ Bogdan Kulik, Waldemar Pałęcki, red., Jest nadzieja, bo jest zycie wieczne (Lublin: Wydawnictwo KUL, 2018); Wstęp i Spis treści zob. apostolstwo.pl, zakładka: „Materiały/ Książki ADS".

${ }^{38}$ Papieska Rada ds. Duszpasterstwa Służby Zdrowia, Nowa Karta Pracowników Stużby Zdrowia, 2016 (Katowice: Księgarnia św. Jacka, 2017), 160.
} 
podjąć próbę opracowania nowych form dotarcia z treściami eschatologicznymi także do dzieci i młodzieży. Do tej pory bowiem adresatami inicjatyw Apostolstwa były przede wszystkim osoby dorosłe.

Należy dodać, że sytuacja pandemii, spowodowanej wirusem wywołującym COVID-19, stała się co prawda przyczyną pewnych trudności w realizacji bieżących zadań Apostolstwa, lecz nie zahamowała rozwoju Stowarzyszenia. Mimo konieczności odwołania niektórych spotkań i rekolekcji, działalność duszpasterska, formacyjna i wydawnicza jest kontynuowana, dzięki czemu grono członków Stowarzyszenia oraz osób, do których dociera chrześcijańska wizja nadziei życia mimo śmierci, powiększa się. Fakt ten świadczy o tym, że tak duszpasterze, jak i członkowie Apostolstwa z zaangażowaniem wypełniają jego misję. Wydaje się, że wypracowane przez lata sposoby działalności Apostolstwa, jak i te, które pojawiły się w związku z pandemią - wspomniane wyżej cykle filmików publikowanych regularnie w Internecie - owocnie służą głoszeniu chrześcijańskiej nadziei życia wiecznego zdolnej do przezwyciężenia wrodzonego lęku przed śmiercią. Dzięki temu istnieje nadzieja, że wiele osób odczuwających lęk o zdrowie i życie, jaki powoduje niestabilna sytuacja epidemiczna, ma szansę odnaleźć w chrześcijańskiej wizji życia, śmierci i wieczności „twardą skałę” - Chrystusa, na której będą mogli się oprzeć.

\section{BIBLIOGRAFIA}

Association de Notre-Dame de la Bonne-Mort. Notice Historique. Tinchebray: Lorfeuvre, 1963. Bajorski, Adam. „Metoda asystowania umierajacym Księdza Jana Berthier jako model metody ogłaszania Królestwa Bożego". W Cor unum et anima una. Księga Jubileuszowa ku czci księdza Jana Berthier Założyciela Zgromadzenia Misjonarzy Świętej Rodziny z okazji 100lecia jego śmierci, red. Adam J. Sobczyk, 95-101. Pelplin: Bernardinum, 2009.

Benedykt XVI. „Nawrócenie oznacza dążenie do wysokiej miary życia chrześcijańskiego, Rzym 17.02.2010”. Opoka. Dostęp: 07.04.2021. http://www.opoka.org.pl/biblioteka/W/WP/benedy kt_xvi/audiencje/ag_17022010.html.

Berthier, Jan. Metoda asystowania umierajacym. Górka Klasztorna, 2015.

Biedrzycki, Władysław. „Przy łożu śmierci. Metoda towarzyszenia umierajacym ks. Jana Berthiera". W Śmierć $i$ wiara $w$ życie pośmiertne $w$ świetle nauk przyrodniczych $i$ humanistycznych, red. Marian Machinek, 257-267. Olsztyn: Hosianum, 2003.

Boulanger, Jean-Claude, bp. List do ks. Prowincjała Polskiej Prowincji Misjonarzy Świętej Rodziny W. Burzawy MSF. Sées, 24.11.2004.

Curia Generalis OSM. Corona dell'Addolorata. Celebrazione della Compassio Virginis. Roma, 1986.

Färber, Egon. „Towarzyszyć umierającym. Pastoralne wskazówki duszpasterza Jana Berthiera MS (1840-1908) oraz ich dalszy rozwój w regułach zakonnych Misjonarzy Świętej Rodziny, cz. 1". Nadzieja i Życie 1(2017): 14-17. 
Färber, Egon. „Towarzyszyć umierającym. Pastoralne wskazówki duszpasterza Jana Berthiera MS (1840-1908) oraz ich dalszy rozwój w regułach zakonnych Misjonarzy Świętej Rodziny, cz. 2". Nadzieja i Życie 3(2017): 4-7.

Górnik, Grzegorz. Sprawozdanie z działalności Filii Stowarzyszenia Matki Bożej Patronki Dobrej Śmierci w Polsce z siedziba w Sanktuarium Maryjnym w Górce Klasztornej za rok 2020. Górka Klasztorna, 2021.

Kania, Stanisław, red. Apostolstwo Matki Boskiej Patronki Dobrej Śmierci. Kraków: Wydawnictwo Zakonu Pijarów, 1992.

Katechizm Kościoła Katolickiego. Poznań: Pallottinum, 1994.

Kopeć, Józef. „Koronka”. W Encyklopedia Katolicka, t. 9, red. Andrzej Szostek, Bogusław Migut, 886-892. Lublin: Towarzystwo Naukowe KUL, 2002.

Kulik, Bogdan. „ADS z Manhattanem w tle”. Nadzieja i Życie 2(2020): 15-20.

Kulik, Bogdan. „Apostolstwo Dobrej Śmierci - historia i misja”. Roczniki Teologiczne 67(2020), 10: 81-92.

Kulik, Bogdan. „Czy możliwym jest, aby o umieraniu i wieczności pisać profesjonalnie, a zarazem interesująco? Uwagi na temat języka współczesnej eschatologii i dzieł ars moriendi". Teologia i Moralność 14(2019), 1(25): 287-306.

Kulik, Bogdan. „De arte moriendi Jana Gersona - średniowieczny przeżytek czy dar dla współczesnych? Próba analizy w świetle dokumentu Aktualne problemy eschatologii Międzynarodowej Komisji Teologicznej (1992)”. Teologia i Moralność 12(2017), 1(21): 185-203.

Kulik, Bogdan. „Dobra śmierć - czyli jaka? Próba odpowiedzi na pytanie na podstawie nauczania K. Rahnera, H.U. von Balthasara i J. Ratzingera (Benedykta XVI)”. Poznańskie Studia Teologiczne 31(2017): 85-115.

Kulik, Bogdan. Gtosić rodzinie Ewangelię o życiu wiecznym. Pelplin: Bernardinum, 2021.

Kulik, Bogdan. „Jak mówić dziś w Kościele o śmierci? Śmierć w kontekście pastoralnym w świetle De mortalitate św. Cypriana z Kartaginy”. Teologia Praktyczna 19(2018): 155-172.

Kulik, Bogdan, red. Materiaty formacyjne. Wieczność ze św. Janem Pawtem II. Pelplin: Bernardinum, 2020

Kulik, Bogdan. „Od paruzji do «paruzjologii», czyli eschatologia w ujęciu Antoniego Nitroli”. Poznańskie Studia Teologiczne 28(2014): 195-211.

Kulik, Bogdan, Waldemar Pałęcki, red., Jest nadzieja, bo jest życie wieczne. Lublin: Wydawnictwo KUL, 2018.

Machinek, Marian. „Towarzyszyć w ostatniej drodze. Metoda asystowania umierajacym ks. Jana Berthier a współczesna troska o umierających". W Cor unum et anima una. Księga Jubileuszowa ku czci księdza Jana Berthier Założyciela Zgromadzenia Misjonarzy Świętej Rodziny z okazji 100-lecia jego śmierci, red. Adam J. Sobczyk, 79-94. Pelplin: Bernardinum, 2009.

„Memento mori - spotkanie online”. YouTube: Wydawnictwo W drodze. Dostęp: 12.04.2021, https://www.youtube.com/watch?v=rjHfxQgTh-M.

Modlitewnik Apostolstwa Dobrej Śmierci. Pelplin: Bernardinum, 1999.

Muraro, Maria M., Maria M. Pedico., „Addolorata”. W Mariologia, red. Stefano De Fiores, Valeria Ferrari Schiefer, Salvatore M. Perrella, 6-16. Cinisello Balsamo, Milano: San Paolo, 2009.

Papieska Rada ds. Duszpasterstwa Służby Zdrowia. Nowa Karta Pracowników Stużby Zdrowia, 2016. Katowice: Księgarnia św. Jacka, 2017.

Pedico, Maria M. El culto de la Virgen de los Dolores desde 1848 a 1950 en la Orden de los Siervos de Maria [b.m.r.w.]. Dostęp: 06.04.2021, http://servidimaria.net/sitoosm/es/historia/ conguno/11.pdf.

„Pogadajmy bez ogródek”. Apostolstwo Dobrej Śmierci. Dostęp: 12.04.2021, https://apostolstw o.pl/multimedia/pogadajmy-bez-ogrodek. 
„Rekolekcje: Co chcesz abym ci uczynił? Gdynia 16-18.03.2018”. Wspólnota Rodziców Po Stracie Dziecka. Dostęp: 08.04.2021, http://www.stratadziecka.pl/aktualnosci/wydarzenia/ 35896/rekolekcje-co-chcesz-aby-ci-uczynil.

„Rekolekcje: Nadzieja zawieść nie może. Gdynia 22-24.03.2019”. Wspólnota Rodziców Po Stracie Dziecka. Dostęp: 08.04.2021, http://www.stratadziecka.pl/aktualnosci/wydarzenia/ 45869/rekolekcje-nadzieja-zawiesc-nie-moze.

„Rekolekcje: W Twoich ranach jest nasze zdrowie. Straszyn 6-8.03.2020”. Wspólnota Rodziców Po Stracie Dziecka. Dostęp: 06.04.2021, http://www.stratadziecka.pl/aktualnosci/wyda rzenia/59193/rekolekcje-06-08-03-2020-straszyn.

„Rozmowy o życiu, śmierci i wieczności”. Apostolstwo Dobrej Śmierci. Dostęp 06.04.2021, https://apostolstwo.pl/multimedia/posluchaj-nas.

Siatka, Roman, red. Historia Stowarzyszenia Matki Bożej Patronki Dobrej Śmierci. Pelplin: Bernardinum, 2008.

Sinayobye, Edouard. Jestem Matka Stowa. Nasza Pani z Kibeho. Przebudzenie na nasze czasy. Ząbki: Apostolicum, 2016.

Skwarczyński, Adam, red. Rękopis z czyśćca. Marki: Michalineum, 2005.

„Stąpając Twardo Po Ziemi”. Apostolstwo Dobrej Śmierci. Dostęp: 06.04.2021, https://apost olstwo.pl/multimedia/stapajac-twardo-po-ziemi.

Stowarzyszenie Matki Boskiej Patronki Dobrej Śmierci. Pelplin: Bernardinum, 1996.

Vernaeckt, Anne-Guillaume. „Préface”. W Sanctuaire de Montligeon. Le Manuscrit du Purgatoir. 5-6. Paris: Pierre Téqui, 2013.

Wajdzik, Lidia. „Apostolstwo na Czarnym Lądzie”. Nadzieja i Życie 1(2019): 11-15.

Werbiński, Ireneusz, Bogdan Kulik i Adam Sobczyk. Jak się nie zagubić w czasie i w wieczności? Spotkanie z Chrystusem jako istota duchowości chrześcijańskiej i rzeczy ostatecznych człowieka. Włocławek: Włocławskie Wydawnictwo Diecezjalne, 2017.

Zapotoczny, Aleksandra. Wszystko postawiliśmy na Maryję. Pelplin: Bernardinum, 2015.

„60 sekund o wieczności”. Apostolstwo Dobrej Śmierci. Dostęp: 06.04.2021, https://apostolst wo.pl/multimedia/60-sekund-o-wiecznosci.

\title{
APOSTOLSTWO DOBREJ ŚMIERCI - DUSZPASTERSTWO, FORMACJA, DZIAŁALNOŚĆ WYDAWNICZA I NAUKOWA
}

\author{
St res z c z e n i e
}

Artykuł jest szczegółową analizą działalności Apostolstwa Dobrej Śmierci, w celu ukazania konkretnych sposobów głoszenia chrześcijańskiej nadziei życia wiecznego. Zagadnienie zostało podjęte w związku z pandemią, spowodowaną wirusem wywołującym COVID-19, która ukazała konieczność nieustannego przypominania wymiaru wiecznego życia ludzkiego. Badanie aktywności Apostolstwa koncentruje się na jej głównych formach i wykazuje znaczącą rolę Apostolstwa w propagowaniu mentalności eschatologicznej tak w czasie pandemii, jak i poza nią.

Słowa kluczowe: dobra śmierć; apostolstwo; duszpasterstwo; formacja. 